\title{
Classroom Management Strategies in English Language Teaching: A Perspective of English Teacher
}

\author{
Rifdah Diniatulhaq, Annafi Ananda Oktaria, Azwar Abbas \\ Universitas Ahmad Dahlan \\ Email: rifdahdini12@gmail.com,
}

\begin{abstract}
The essence of classroom management is the creation of more conducive student learning conditions. The conducive learning conditions are the most important prerequisite for the smooth implementation of student learning activities, so that the smooth learning process influences the learning outcomes more optimally. Good class management is one that can serve and help students' needs in learning. Therefore, the characteristics and needs of students are the first things that need to be known and taken into account by the teacher as well as possible. This present study tries to analyze classroom management strategies in English Language Teaching of three junior high school in Yogyakarta. To collect the data, the researchers used semi-structure interview and the obtained data were analyzed with descriptive-qualitative method.The result showed that there are three dominant aspects of classroom management system, namely; curriculum and instructional management's (i.e. curriculum planning, making the lesson plan, scheduling, method implementation learning and assessment), management behavior (i.e. teacher sets and enforces the rules and the procedure, teacher starts the lesson, teacher builds relationships with students, teachers apply discipline and consequences and teacher is involved in the process learning), and management of the environment (i.e. class settings namely structuring furniture and determining the number of students).
\end{abstract}

Keywords: classroom management, strategies, english teacher.

\section{INTRODUCTION}

The quality resources are important for a country to become a developed, strong, and prosperous. Efforts to improve the quality of human resources cannot be separated from the problems of national education. Teachers have a very large contribution to the success of learning in school. The teacher has a role in helping the development of students to achieve their life goals optimally(Aswad 2017). In the classroom the teacher carries out two main activities namely teaching and learning activities and classroom management.

According to Allen (2010), Classroom management is complex set of skills that includes 
much more than being able to influence and control student behavior, there remains an overall impression that classroom management is primarily about discipline. In line with this, McCreay (2013) stated that classroom managements are the methods and strategies an educator uses to maintain a classroom environment that is conducive to students' success and learning. Thus, classroom management is a set of skills that teachers should mastered in order to maintain the class in a very positive and discipline that eventually leads students to succes in teachinglearning process

A teaching and learning process could not go as intended regardless of how well the teaching plans, the methods and techniques, or even the sophistication of the supporting media (Fakhruddin, Selle, and Nurchalis 2019). If teachers do not have a good awareness and capability on managing the class. Managing classrooms means managing the complexity of the class. It deals with how to give an instruction, how to treat misbehave students and prevent it to happen again and also how to deals with an unexpected situations that may disturb the class. According to Brown (2001), There are several elements of classroom management in the physical environment of the classroom such as the sight, sound and comfort; the seating arrangements; the use of the board and the equipments needed in the class. Successful teachers are often very effective managers of the classroom environment (Halik et al. 2019). They create a positive learning community where students are actively involved in their own learning and the management of the classroom.
As far as English Language Teaching is concern, classroom management is one of the important aspects in teaching English. Classroom management that used by the teacher can influence students' paradigm regarding to the importance of English. English teacher are challenged to be able to manage the classroom, including creating and maintaining of the optimal learning conditions (Aswad et al. 2019). Therefore, this research is intended to investigate the Clasroom management strategies in English language teaching from the teachers perspective in three junior high school in Yogyakarta.

\section{LITERATURE REVIEW}

There were several previous studies which had been conducted in relation to this present study. (Popescu, 2014) conducted a study on English language teachers' perceptions regarding classroom management strategies and techniques, after completion of their English language Practicum in primary and secondary schools. The similarities between Popescu's research and this research is the research subject, both of these studies used English teachers as a subject. While, the differences is the previous research used the quantitative study and the technique of getting the data used is open ended question. (Muhammad, 2019) conducted study on analyzing the strategies for managing classes by the teachers to overcome learning difficulties in slow learners. The similarities between Muhammad's research and this research are the method used is qualitative study and the technique of getting the data used in both researches is semi structured interview. (Delceva, 2014) This study is to discover the path that enable teachers to manage their work 
with students in the classroom. Method that delceva's research used is quantitative study and the technique of getting the data used questionare.

\section{METHOD}

This research belong to a qualitative research which used a case study design. Qualitative research focuses on discovering and understanding the experiences, perspectives, and thoughts of participants. In line with this statement, (Aswad et al. 2019) explained that qualitative research is an inquiry process of understanding or exploring a social or human problem. In addition, Berg, et al. (2004) defined a case study as a type of qualitative research approaches that is used to analyze, interpret, and describe a phenomenon in depth a single case experience. This design is used since the researchers intended to gain deepth-understanding on the perspective of english teacher in classroom management strategies in english language teaching.

The sample of this research are three english teachers who currently teaching at SMP Negeri 16 Yogyakarta, SMP Muhammadiyah 8 Yogyakarta and SMP Pangudi Luhur 1 Yogyakarta . The three english teachers were females and aged around thirty five years old. The researcher played the main role of the study in the process of collecting the data until the data is saturated. The researcher described, analyzed, and interpreted the data in this study. In collecting the data, the researcher used interview guide, voice recorder, some pictures and note to collect the data. Kind of interview used in this research was semistructured interview, which is less formal types in which both of researcher and informants are placed in freedom interaction. We used semi-structured interview because they provide a very flexible technique for small scale reserach (Drever,1995).

According to Indawan, Sulaiman \& Susanti (2017: 83) state that interview is a technique of collecting the data through direct communication between the interviewer and the respondent. This research was considered as a descriptivequalitative method used to describe the existing phenomenon. In the other hand, ج. روستايى،م. فاضلى ع.ا. رشيديمهرآبادي، استفادهازنانوفيلتراسيون درتصفيه آبهاي لبشور No Title, n.d.) stated that a qualitative interview occurs when researcher ask one or more participant through some open questions and record the answer. (Bruno 2019) states: A descriptive method in descriptive research is to describe, compare, contrast, classify, analyze, and interpret the entities and the events that constitute their various fields of inquiry. It is concerned with conditions or relationships that exist; practices that prevail; beliefs, points of views, or attitudes that are held; processes that are going on; effects that are being felt; or trends that are developing. At times, descriptive research is concerned with how what is or what exists is related to some preceding event that has influenced or affected a present condition or event. In this case, descriptive research was used to establish the existence of phenomenon by explicitly describing them.

\section{FINDING AND DISCUSSION}

Relating to the implementation of classroom management in all three schools, the study findings this is that all participants are at all three schools carry out management classes that involve instructional and curriculum management, behavioral management 
and environmental management and there are different variations in each school.

Instructional and curriculum management includes curriculum planning, making the lesson plan, scheduling, method implementation learning and assessment. Management behavior includes how the teacher sets and enforces the rules and the procedure, how the teacher starts the lesson, how the teacher builds relationships with students, how do teachers apply discipline and consequences and how the teacher is involved in the process learning. Management of the environment consists of class settings namely structuring furniture and determining the number of students make it clear. The interview result from management implementation findings classes in all three schools are presented at Table 1.

Tabel 1. Classroom Management Matrix in Three Junior High Schools in Yogyakarta

\begin{tabular}{|c|c|c|c|}
\hline $\begin{array}{c}\text { Classroom Management } \\
\text { System }\end{array}$ & School A & School B & School C \\
\hline $\begin{array}{l}\text { curriculum and instruc- } \\
\text { tional management }\end{array}$ & 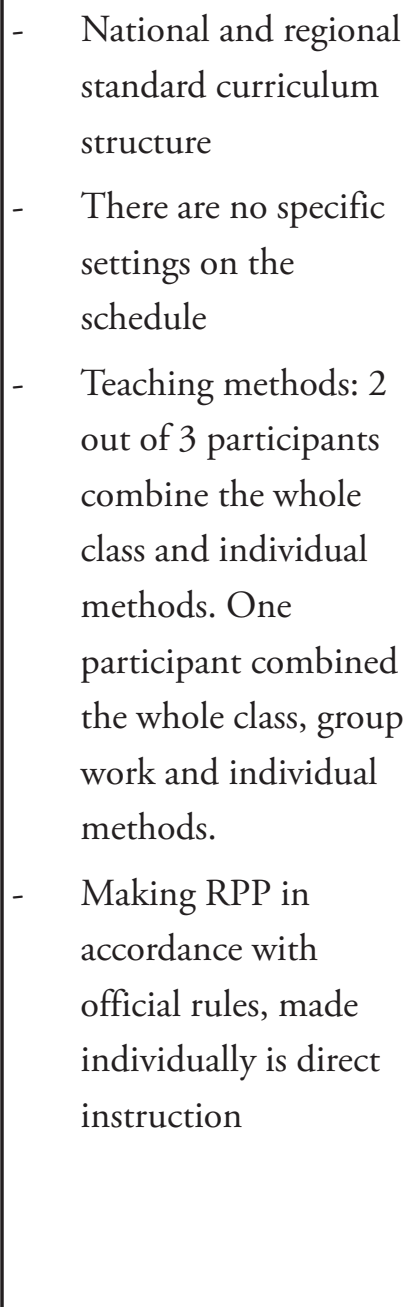 & 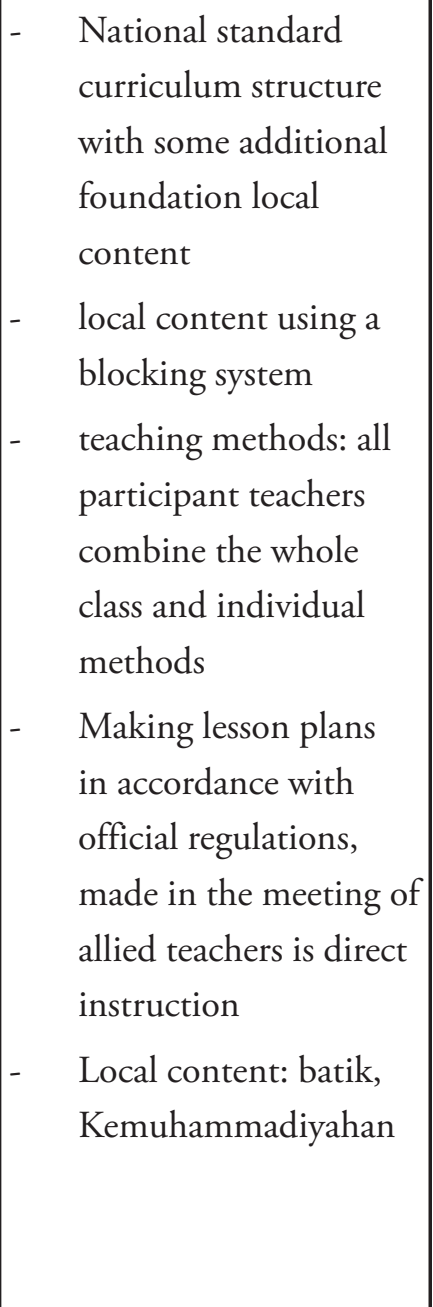 & 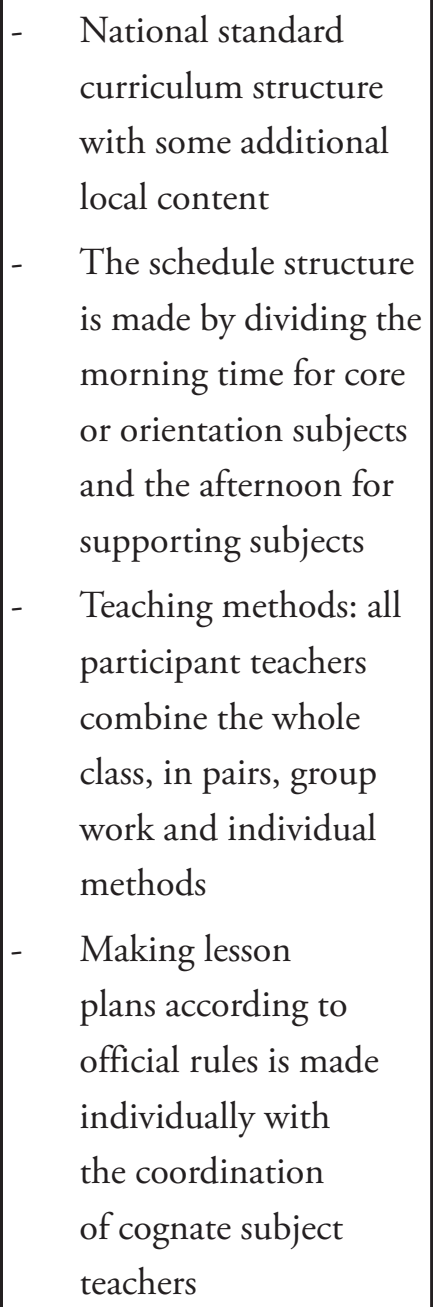 \\
\hline
\end{tabular}




\begin{tabular}{|c|c|c|c|}
\hline $\begin{array}{c}\text { Classroom Management } \\
\text { System }\end{array}$ & School A & School B & School C \\
\hline $\begin{array}{l}\text { environmental manage- } \\
\text { ment }\end{array}$ & 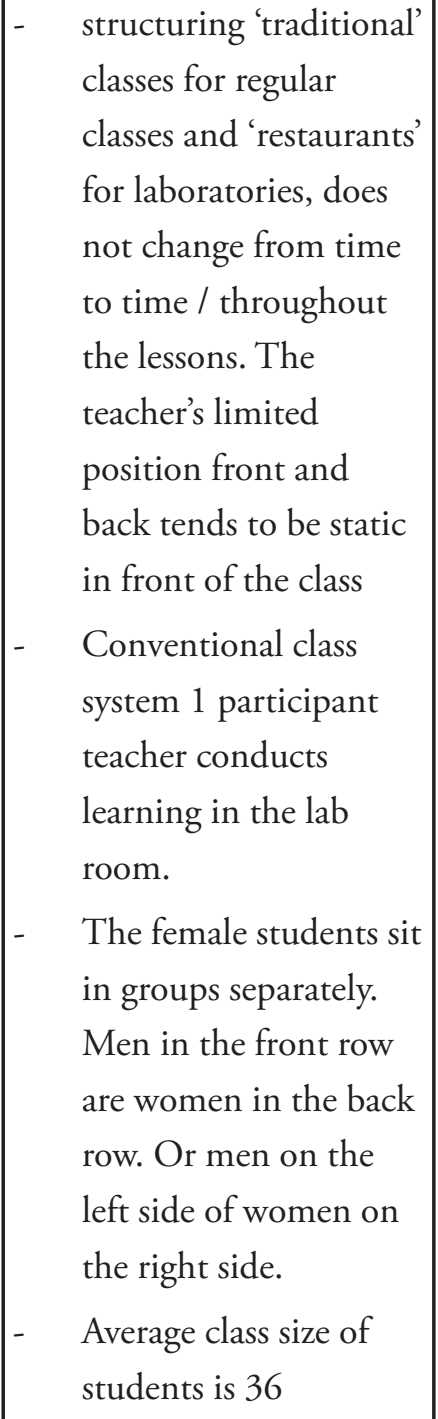 & \begin{tabular}{|l} 
- \\
'traditional' classroom \\
structuring, does not \\
change over time / \\
lessons. The teacher's \\
position tends to be \\
static in front of the \\
class \\
heterogeneous students \\
consisting of male and \\
female students \\
conventional class \\
system - there is no \\
schedule, student work \\
and bulletin board on \\
the classroom wall \\
the number of class \\
students is 26 - 30 \\
students
\end{tabular} & 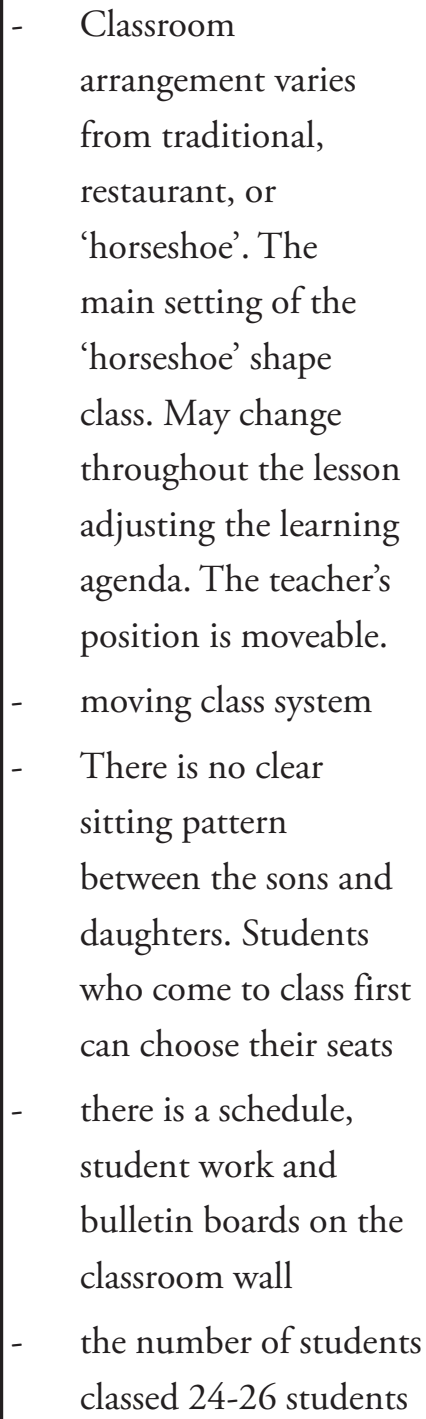 \\
\hline
\end{tabular}




\begin{tabular}{|c|c|c|c|}
\hline $\begin{array}{c}\text { Classroom Management } \\
\text { System }\end{array}$ & School A & School B & School C \\
\hline behavioral management & 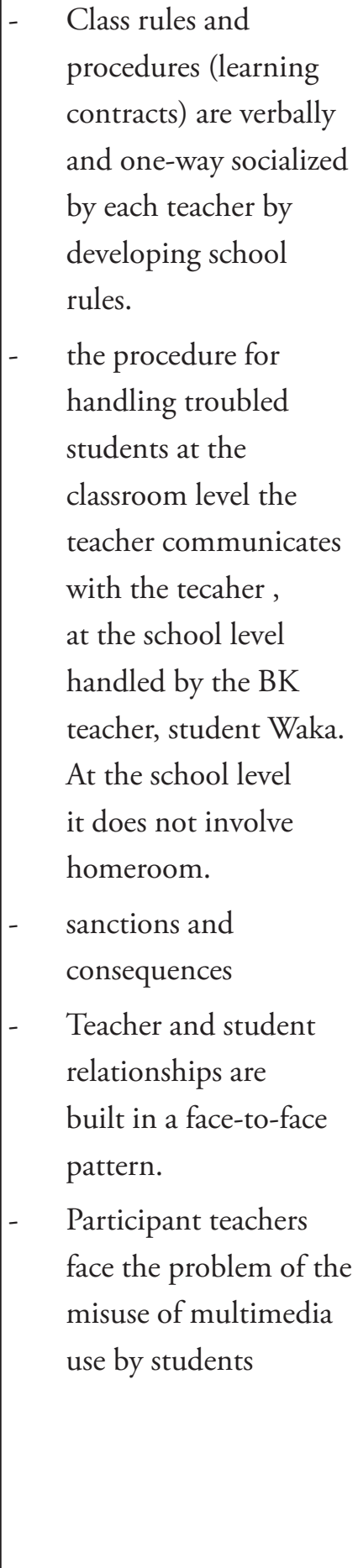 & 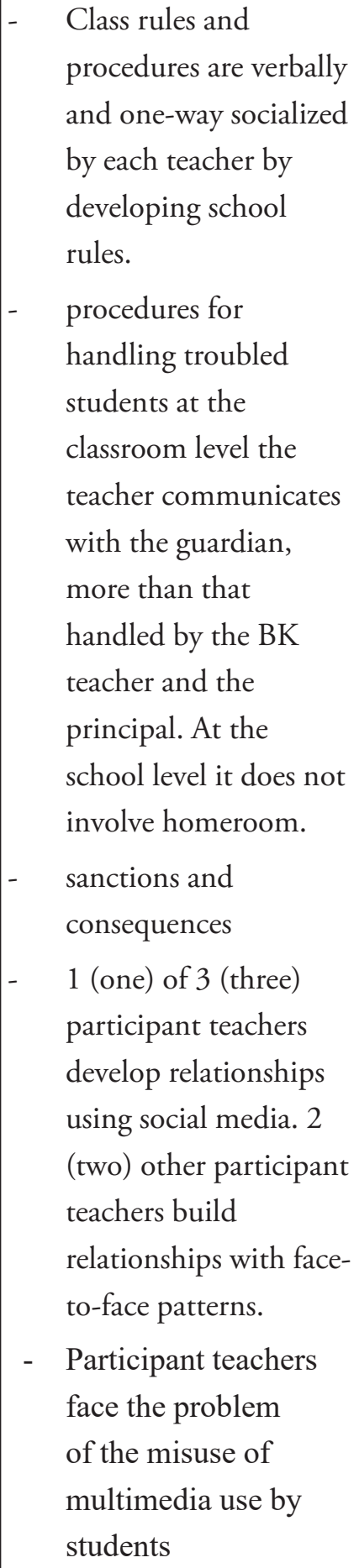 & 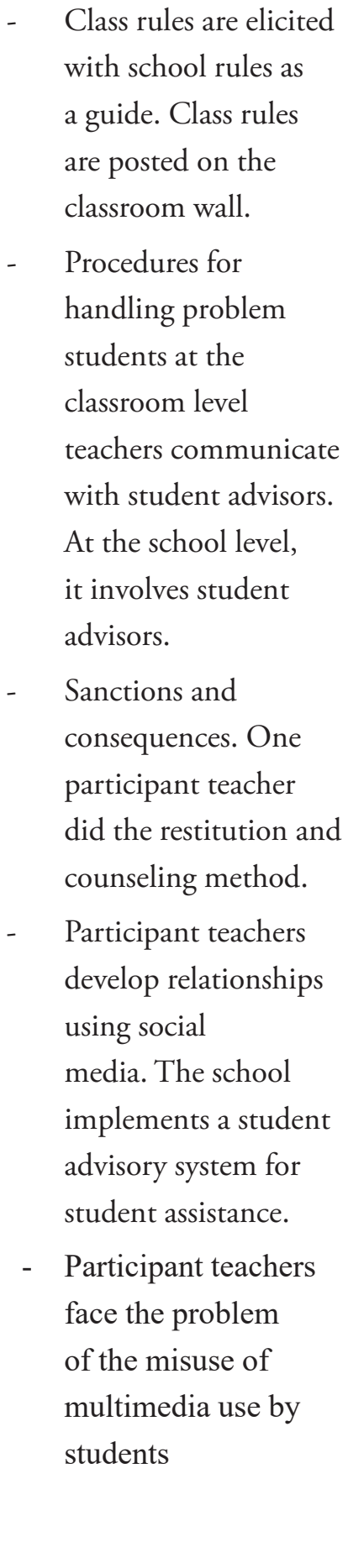 \\
\hline
\end{tabular}


From this table, it can be analyzed that at the school level, support towards class management efforts being very substantial. School support in the form of rules and procedures that are clear regarding the use of multimedia equipment as practiced by schools $\mathrm{C}$ at least reduces the problem of cellphone abuse in class. This is also the case with other behavioral problems that are challenging within classroom management faced by teachers participants in all three schools namely crowded / talk to friends outside the material, fighting, bringing food / selling food / drink in class, sleep, and late for class.

As confirmed by Sugai and Horner (2006, pp.245-259) that support overall management behavior at the school level is prevention strategies and the basis for the effectiveness of class management. Application behavioral management at the class level will it becomes easier if the environment positive and well-managed school. The school's support will also making classroom management practices more sustainable.

This indication shows that the teachers were not given a briefing about class management and skills behavioral management which involves understanding class management and techniques that are directly related to their experience in the field. They also did not get supervision adequate in the context of management real behavior either from the service or the government or from schools / foundations.

In the pedagogical context, the lack of skills of teachers to deal with the problem of building relationships with students and managing skills student behavior is an indication of obstacles will be the effectiveness of class management.

The importance of providing teachers with classroom management centered students, stated by Coggins (2009, p.10): "If we can help teachers to be facilitators of their own classroom environments, then we increase the likelihood that the students will learn. The goal is to make teaching a joy, not a chore. If these new educators find the appropriate way to involve their students in the learning process and still have fun doing it, they too will enjoy the school day."

The debriefing was carried out mainly at the beginning of the teacher's work and then maintained continuously will help the teacher get the skills needed in five first year of his teaching experience. How to be a good facilitator, how the art of building relationships with students or even parents of students and how to manage behavior becomes a crucial part of a teacher's first training.

In line with this study too, Oliver \& Recshly (2007, pp.1-13) noted the importance of the relationship between teachers and students with the effectiveness of the teacher. Oliver and Reschly insists that the teacher is having high effectiveness is the teacher who has the ability to implement strategies that are right in behavior management in its class. Class management includes management class behavior as a whole, certain groups within the class as well as individual.

Management of this behavior becomes part of class management planning designed by a teacher comprehensively (Oliver and Reschly, 2007, p.8). 
In this context, research this shows that a close student relationship increases effectiveness class management. The teacher feels more successful in mastering and directing the class when they become the mayor or they feel close to their students because the teacher becomes a student advisor.

The use of nonverbal techniques also recorded in this study as incorrect an effective effort made by the teacher participants in making the classroom atmosphere be conducive. Non-verbal techniques such as pausing to stop the explanation, eye contact / eye contact, approaching or stay away is an example of an action conducted by the participant teacher. Action which is thus, it immediately stops the commotion in the classroom and prevents the commotion from becoming more widespread. Other non-verbal techniques such as gestures typical as well as the applause shown by the teacher to show enthusiasm for the class.

This note underlines what delivered by Grubaugh (1989,p.39) that "All the non-verbal variables of language can be used as strategies to establish and reinforce the disciplinary message to the students ". All languages non-verbal can be used as a strategy to send disciplinary message signals to students. One of them is by "using silence effectively, a teacher can allow inferences to work with students ". By using strategy silence effectively can actually make teachers increasingly understand what is expected by their students (Grubaugh, 1989, p.39).

\section{CONCLUSION}

There are three aspects relating to the classroom management system that faced by three school, namely: curriculum and instructional management, behavioral management and environmental management. The three school has different system of classroom management. The results of this research showed that Teaching and curriculum management includes curriculum planning, lesson planning, scheduling, learning implementation methods and assessments. Management behavior includes how the teacher establishes and enforces rules and procedures, how the teacher starts the lesson, how the teacher builds relationships with students, how the teacher applies discipline and consequences and how the teacher is involved in the learning process. Environmental management consists of class settings namely the arrangement of furniture and determining the number of students makes it clear.

\section{REFERENCES}

Allen, K. P. (2010). Classroom management, bullying, and teacher practices. The Professional Educator, $34(1), 1-15$.

Aswad, Muhammad. 2017. "The Effectiness English Camp (A Model in Learning English as the Second Language)." In ASEAN/Asian Academic Society International Conference Proceeding Series.

Aswad, Muhammad, Fathu Rahman, I.M Said, B Hamuddin, and Nur Fadillah Nurchalis. 2019. "A Software to Increase English Learning Outcomes: An Acceleration Model of English as the Second Language." 2019. https://www.asian-efl-journal. com/monthly-journals/2019-monthly-journals/ volume-26-issue-6-2-2019/.

Bruno, Latour. 2019. 済無No Title No Title. Journal of Chemical Information and Modeling. Vol. 53. https:// doi.org/10.1017/CBO9781107415324.004.

Fakhruddin, Zulfah, Amzah Selle, and Nur Fadillah Nurchalis. 2019. "Technology-Based Teaching Material Development Training for Pre-Service Teachers to Improve Students' Learning Outcomes." 
NOBEL: Journal of Literature and Language Teaching 10 (1): 87-102. https://doi.org/10.15642/ NOBEL.2019.10.1.87-102.

Halik, Abdul, St Wardah Hanafie Das, Muhammad Aswad, M. Syakir Rady, Muhammad Siri Dangnga, and M. Nasir S. 2019. "Empowerment of School Committee in Improving Education Service Quality at Public Primary School in Parepare City." Universal Journal of Educational Research 7 (9): 1956-63. https://doi.org/10.13189/ujer.2019.070915.

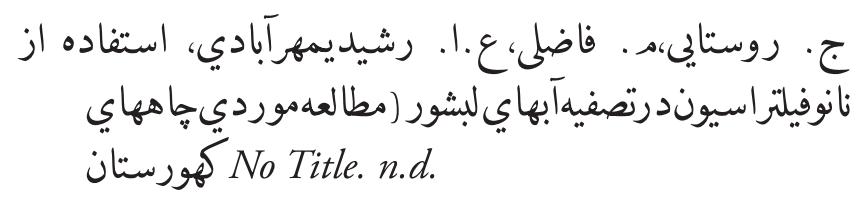

Bruno, L. (2019). 済無No Title No Title. In Journal of Chemical Information and Modeling (Vol. 53). https://doi.org/10.1017/CBO9781107415324.004

Creswell. (2012). Educational research planning, conducting and evaluating quantitative and qualitative research. Upper Saddle River, N.J: Merrill.

Delceva, Jasmina. (2014). Classroom Management. International Journal of Cognitive Reseacrh in Science, Engineering and Education. 2 (1): 51-56.
Drever, E. (1995). Using Semi-Structured Interviews in Small-Scale Research. A Teacher's Guide. Edinburgh: Scottish Council for Research in Education.

Nawawi, Hadari. (2000). Organisasi Sekolah dan Pengelolaan Kelas Sebagai Lembaga Pendidikan. Jakarta : Gunung Agung.

Indawan., Sulaiman, MGS., \& Susanti, R. (2017). Metodologi penelitian pendidikan bahasa, (1st ed.). Palembang: Roemah Sufie.

Muhammad, Julkifli. (2019). Strategi Guru Mengelola Kelas Dalam Mengatasi Kesulitan Belajar Pada Anak Lamban Belajar. Pascasarjana Universitas Islam Negeri Maulana Malik Ibrahim. Malang.

McCreary, Randin. Classroom management. In EHow. Retrieved Januari 18, 2020. (www.ehow.com/ about_5438989_classroom-managementdefinition)

Popescu, Teodora. (2014). Classroom Management Strategies and Techniques: A Perspective of English Teacher Trainees. JoLIE. 7. 143-160. 